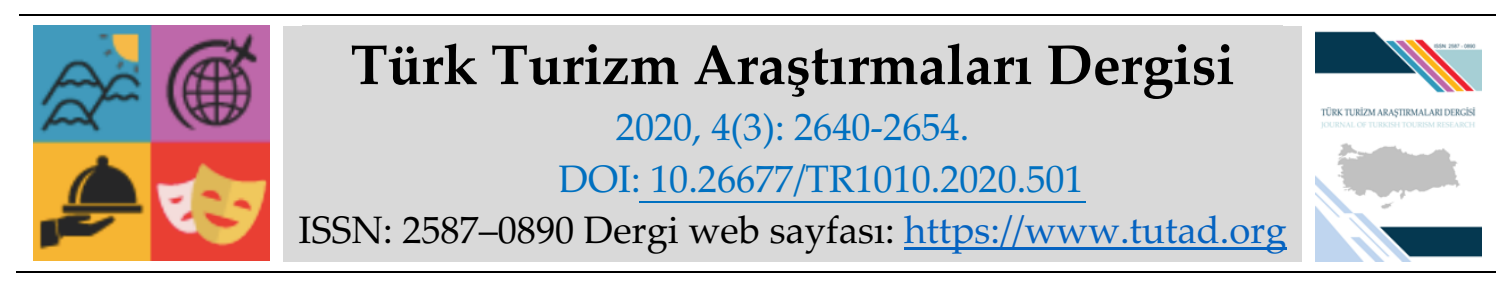

ARASTIRMA MAKALESI

\title{
Kars'ın Yerel Yemekleri ve Yerel Ürünlerin Kars'taki Yiyecek İçecek İşletmelerinde Kullanımının Sürdürülebilir Gıda Kapsamında Değerlendirilmesi
}

Dr. Öğr. Üyesi Gülşen BAYAT, Iğdır Üniversitesi, Turizm Fakültesi, Iğdır, e-posta: gulsen.bayat@igdir.edu.tr ORCID: https://orcid.org/0000-0001-9955-3075

Öz

Bu çalışmanın amacı, gıda sürdürülebilirliği anlayışı içerisinde yiyecek ve içecek işletmelerinde yerel mutfak ürünlerine verilen önemi belirlemek ve bu işletmelerdeki mevcut uygulamayı değerlendirmektir. Nitel araştırma teknikleri arasında yarı yapılandırılmış görüşme tekniği kullanılmıştır. Amaçlı örnekleme yöntemi ile belirlenen yetkililer (restoran müdürü, işletme sahibi ve şef) yiyecek ve içecek işletmeleri $(n=10)$ ile görüşmeler yapılmıştır. Bu test sonucunda, yerel gıda ürünlerinin işletme menülerinde $(n=10)$ olduğu tespit edilmiştir. Kars kazının en önemli yerel mutfak ürünü olduğu ve Kars'ın gastronomik ürünü haline geldiği belirlenmiştir. Sürdürülebilirlik, işletmeler için bir motivasyon kaynağı olarak ifade edilmemiştir. İşletmelerin sadece birinin gıda sürdürülebilirliği algılamasına sahip olduğu, mutfak kültürünün sürdürülebilirliğinin ise sekiz tanesinin hedefleri arasında olduğu belirlenmiştir. Yerel gıda ürünlerinin bu örnek için yiyecek ve içecek işletmelerinde yer aldığı düşünülürse, bunun sürdürülebilir gıda bilinci ile yapılmadığı sonucuna varılmıştır.

Anahtar Kelimeler: Yerel Ürün, Sürdürülebilir Gıda, Kars Kazı, Kars Yiyecek İçecek İşletmeleri. Makale Gönderme Tarihi: 24.04.2020

Makale Kabul Tarihi: 06.07.2020

\section{Önerilen Atıf:}

Bayat, G. (2020). Kars'ın Yerel Yemekleri ve Yerel Ürünlerin Kars'taki Yiyecek İçecek İşletmelerinde Kullanımının Sürdürülebilir Gıda Kapsamında Değerlendirilmesi, Türk Turizm Araştırmaları Dergisi, 4(3): 2640-2654.

(C) 2020 Türk Turizm Araştırmaları Dergisi. 


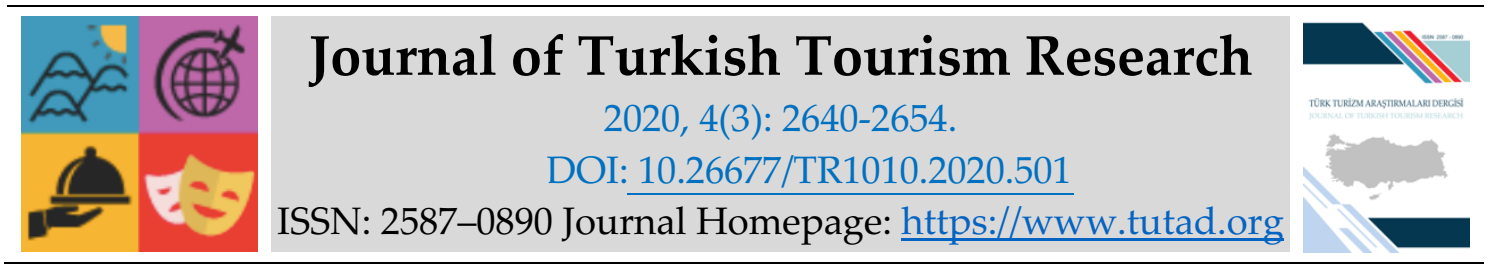

\title{
$\underline{\text { RESEARCH PAPER }}$
}

\section{The Evaluation of Kars 'Local Meals and the Use of Local Products in Food and Beverage Facilities in Kars Within Sustainable Food}

Assistant Prof. Dr. Gülşen BAYAT, Iğdır University, Faculty of Tourism, e-mail: gulsen.bayat@igdir.edu.tr

ORCID: https://orcid.org/0000-0001-9955-3075

\begin{abstract}
The aim of this study is to determine the importance given to local cuisine products in food and beverage enterprises within the understanding of food sustainability and to evaluate the current practice in these enterprises. Among the qualitative research techniques, semi-structured interview technique was used. Interviews were made with the authorities (restaurant manager, business owner and chef) determined by the purposeful sampling method $(\mathrm{n}=10)$. As a result of this test, it has been determined that local food products are in operating menus $(n=10)$. It has been determined that Kars goose is the most important local cuisine product and has become the gastronomic product of Kars. Sustainability has not been expressed as a source of motivation for businesses. It has been determined that only one of the enterprises has the perception of food sustainability, and the sustainability of the culinary culture is among the targets of eight. Considering that local food products are included in the food and beverage establishments for this example, it is concluded that this is not done with sustainable food awareness.
\end{abstract}

Keywords: Local Product, Sustainable Food, Kars Goose, Kars Food and Beverage Companies. Received: 24.04 .2020

Accepted: 06.07.2020

\section{Suggested Citation:}

Bayat, G. (2020). The Evaluation of Kars 'Local Meals and the Use of Local Products in Food and Beverage Facilities in Kars Within Sustainable Food, Journal of Turkish Tourism Research, 4(3): 2640-2654.

(C) 2020 Türk Turizm Araştırmaları Dergisi. 


\section{Gíriş}

Yerel ürün belirli bir coğrafik bölgeye veya yöreye ait üründür. Bölgelerin doğal koşulları, karakteristik özellikleri, deneyimleri ve gelenekleri ile oluşan yerel ürünler bölgelerin ekonomik gelişimini ilerletmek için kullanılır (Kelemci ve Ceritoğlu, 2010). Yöresel ürünler, farklı bölgelerde üretilen ve üretildiği yöreye has tat, aroma ve bileşim gibi özellikler taşırlar (Tan, 2009). Başka bir ifade ile yerel gıda, bölge, şehir veya il sınırlarında üretilen tarımsal ve hayvansal kaynaklı gıda ürünleridir (Kang ve Rajagopal, 2014). Daha geniş bir tanımla yöresel, bölgesel ya da geleneksel ürünler; coğrafi açıdan bir bölge veya yöreye özgüdür. Bu ürünlerin kalitelerini üretildiği bölge/yörenin doğal koşulları ve bölgesel özellikleri etkiler (Demirbaş vd., 2006:49).

Turizmin önemli bir parçası olan yiyecek içecek deneyimlerinin en önemli unsurlarından biri de yöresel mutfaktır. "Yöresel mutfak kavramı; yöreye özgü olan ürünler ile yöresel adetlerin birleştirilmesi sonucu ortaya çıkan, yöre halkı tarafından kendine özgü usullerde pişirilerek sunulan ve dini ya da milli duygularla tasarlanan yiyecek ve içeceklerin tamamı olarak" tanımlanabilir (Şengül ve Türkay, 2015:600). Etnik, bölgesel ve yerel yemekler destinasyonların en güçlü belirleyicileridir (Willk, 2006). Bir yörenin en ayırt edici özelliklerinden biri de mutfağıdır. Destinasyonların sahip oldukları cazibe unsurlarından olan yöresel mutfak kültürü, son dönemlerde önemli bir çekicilik oluşturmaktadır ve yöresel yiyecek ve içecekler turist çekme motivasyon yaratıcı etkisi ile birçok çalışmanın konusu olmuştur (Long, 2003; Kim vd., 2013; Bayat, 2018; Bayat, 2019).

Bir bölgedeki/yöredeki toplulukları daha iyi tanıyabilmek için tükettikleri gıda ürünleri ve mutfak özellikleri bir araç olarak kullanılmaktadır. Doğu Anadolu Bölgesinin önemli şehirlerinden biri olan Kars'ın mutfak kültürü un ve etin yoğunlukla kullanıldığı bir yapıdadır. Bozkır iklim bitki örtüsünün hâkim olduğu ilde, en belirgin geçim kaynağı hayvancılıktır. Geniş düz meralara sahip olan Kars'ta büyük ve küçükbaş hayvancılık yaygın olarak yapılmaktadır. İklim özellikleri sebze ve meyve yetiştiriciliğine sınırlı düzeyde izin vermektedir. Kış mevsiminin uzun olması, yaz aylarının kısa olması tarım faaliyetlerini sınırlandırmıştır. Kars'ta tarımsal faaliyet olarak en çok arpa ve buğday yetiştirilmektedir ve arpa hayvanların beslenmesi için daha çok kullanılmakta, buğday ise yöresel yemeklerden bazılarının hammaddesini oluşturmaktadır.

Yerel gıda kullanımı, gıdaların sürdürülebilirliğinin sağlanmasında büyük önem taşıdığı için yerel yiyecek içecek işletmelerinde yerel gıda kullanım durumunu belirlemek oldukça önemlidir. $\mathrm{Bu}$ nedenle öncelikle çok eski zamanlardan beri yörede yaşayan insanların tükettikleri ve günümüze kadar gelmiş Kars'ın yerel yemekleri hakkında bilgi verilmiş, sonrasında nitel araştırma yöntemi ve yarı yapılandırılmış görüşme formu kullanılarak, yiyecek içecek işletmelerinde yerel gıda ürünlerinin ve özellikle Kars kazının mevcudiyet seviyesinin ne olduğuna yönelik sorular işletmelere yöneltilmiş ve sonuçlar bulgular kısmında değerlendirilmiştir.

\section{Kars'1n Sürdürülebilir Yöresel Yemekleri}

1987 yılında Dünya çevre ve Kalkınma Komisyonu tarafından Brundtland Raporuna göre sürdürülebilirlik, "Geleceğin ihtiyaçlarını karşılayabilecek düzeyde kalarak, bugünün ihtiyaçlarını karşılayabilmek" şeklinde tanımlanmıştır (Lehtinen, 2012; Doğan ve Yağmur, 2017). Biraz daha açık bir ifade ile sürdürülebilirlik, toplumların sahip olduğu kaynakların geleceği de düşünerek ve korunarak kullanılmasıdır. Sürdürülebilir gıda, gıda üretim, işleme, dağıtım ve tüketim aşamalarını kapsayan ve gıda sistemlerinde sürdürülebilir kalkınma anlayışıyla aynı doğrultuda ilerleyen bir anlayıştır. Bu anlayış, insan sağlığı için önemli ve gerekli olan gıda 
üretim ve tüketiminin doğal kaynaklar üzerindeki etkisine dayandırılmaktadır (Atay Haspolat, 2015).

Kars'ın yöresel mutfağını yiyecek içecek işletmelerinde sürdürülebilir gıda kapsamında değerlendirebilmek için, Kars yöresi yiyecek içecek işletmeleri menülerinde yer edinmiş bazı yöresel yemekler tanıtılacaktır. Bunlar sırasıyla yöresel adlarıyla Haşıl, Hangel, Piti, Kete, Umaç Helvası, Hörre Aşı, Evelik Aşı, Erişte Aşı, Ayran Aşıdır.

\section{Haşıl}

Kars'ın en eski yöresel yemeklerinden biri olan Haşıl, Karslıların beğenerek tükettikleri bir besindir. Haşılın hammaddesi buğdaydır. Buğday değirmenlerde yıkanır ve içerisindeki yabancı maddeler (taş, kum, diğer küçük otlar) temizlenir ve buğdaylar değirmende belli oranlarda dövülerek yarma (kırık buğday) haline dönüştürülür. Yarma haşılın hammaddesidir. Haşıl pişirmek için yarma bir tencereye konulur ve içerisine bolca su ve biraz da yağ ilave edilir. Yaklaşık 2-3 saat kısık ateşte sürekli suyunu çekene kadar karıştırılır. Hazır hale gelmiş haşıl eritilmiş tereyağı ve sarmısaklı yoğurt ile sıcak servis edilir. Görsel 1.

\section{Hangel}

Etsiz yaprak mantı olarak da isimlendirilen bu yemeğin temel hammaddesi undur. Un, su ve tuz karıştırılarak, sert bir hamur haline getirilir. Hamur yaklaşık 300-400 gr yuvarlak bezeler haline getirilir. Bu bezeler oklava yardımıyla iyice açılır, açılan hamur kare şeklinde kesilir. Kesilen bu hamurlar kaynar suya atılır ve yaklaşık 5-6 dakika pişirilir. Haricinde tereyağı ile soğan kavurulur ve bol sarımsaklı yoğurt hazırlanır. Geniş bir kabın altına sarımsaklı yoğurt sürülür, üzerine hangeller dökülür, hangelin üzerine tekrar sarımsaklı yoğurt onun üstüne de tereyağı ile kavrulmuş soğan dökülür. Görsel 2.



Görsel 1: Haşıl

Kaynak: Kars İl Kültür ve Turizm Müdürlüğü



Görsel 2: Hangel

Kaynak: Kars İl Kültür ve Turizm Müdürlüğü

\section{Piti}

Piti, Kafkasya Türklerinin yemeğidir. Kars'tan başka İran ve Iğdır'da da pişirilmektedir. İran'daki ismi Abguş, Iğdır'daki ismi ise Bozbaş'tır. Piti yemeği için kullanılan malzemeler kuzu incik, kuyruk yağı, nohut, zerdaçal baharatı ve tuzdur. Akşamdan ıslatılan nohutlar yaklaşık 30 dakika 
haşlanır. Kuzu inciklerde yaklaşık 1saat haşlanır ve içerisine kuyruk yağ 1 ilave edilir. Hazırlanan tüm malzemeler Piti özel kabına konulur ve odun fırınında yaklaşık 5-6 saat pişirilir (Bayat, 2019). Görsel 3.

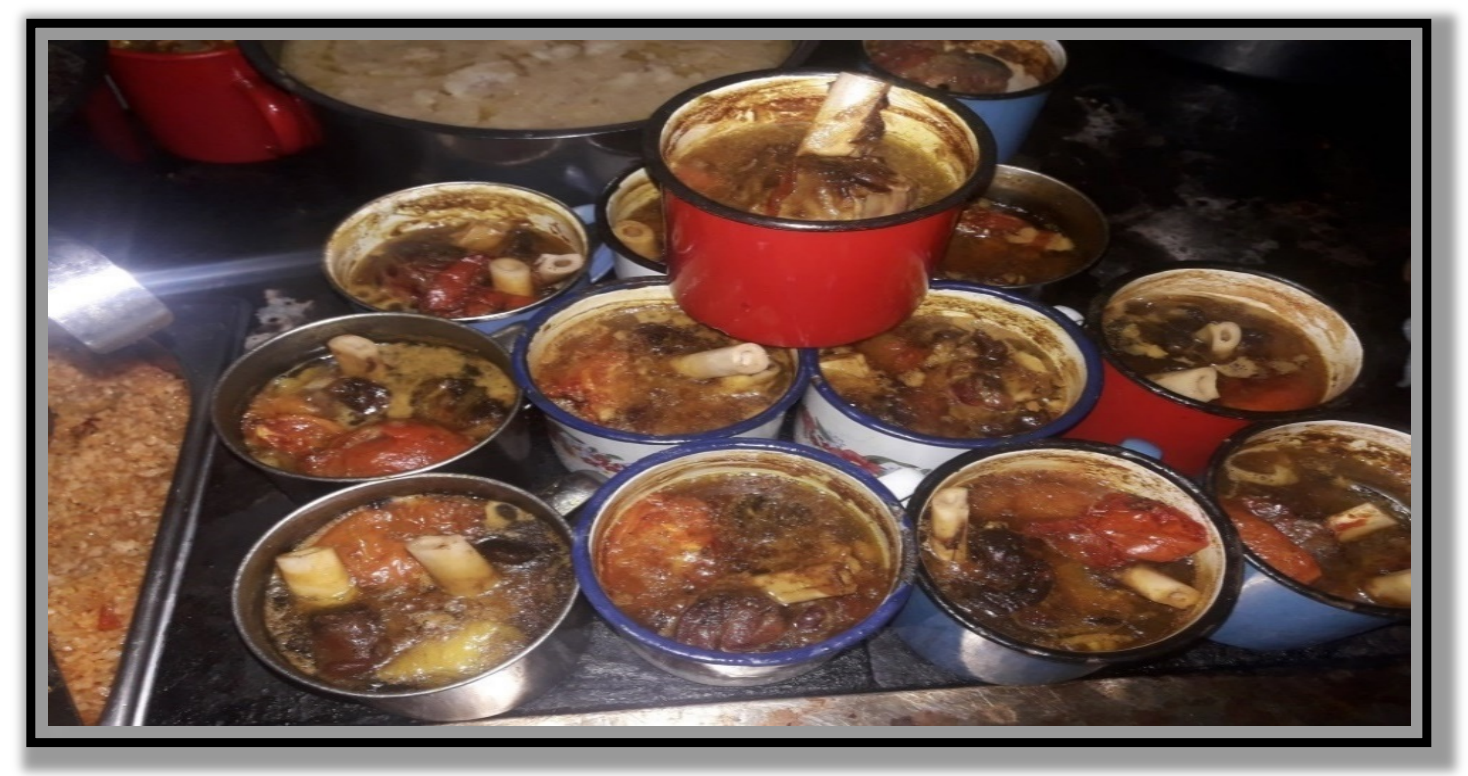

Görsel 3: Piti

Kaynak: Görsel yazar tarafından çekilmiştir.

\section{Kete}

İç malzemesi süt, yumurta, tereyağı, tuz, şeker tozu ve mayadır. Yaklaşık iki kilo süte, 4 yemek kaşığı tereyağı, bir yemek kaşığı tuz, bir tatlı kaşı̆̆ı şeker tozu ve maya eklenir. Tüm bu malzemeler içerisine yeteri miktarda un eklenir ve karışım hamur haline dönüştürülür. Hamur mayalanmak için beklemeye bırakılır. Ketenin iç malzemesi için tereyağı, un ve tuz gereklidir. Tercihe göre tuz yerine şeker de ilave edilebilir. Tereyağı, un, tuz/şeker kısık ateş üzerinde iyice ovularak kete içi oluşturulur. Mayalanan hamurdan büyük bezeler oluşturulur ve bu bezeler yuvarlak yufka halinde açılır. Açılan yufka yağlanır ve dört kat şeklinde katlanır. Katlanan yufkanın ortasına bezelerden biraz az iç malzeme konulur ve hamur iç malzeme dışarı çıkmayacak şekilde bükülür. Bükülen hamur el yardımıyla bastırılarak büyütülür. Elde edilen hamur üzerine yumurta sarısı ve süt karışımı sürülerek fırına verilir. Kars yöresinde özellikle köylerde tandırda pişirilen kete daha çok kabul görmektedir. Görsel 4.

\section{Umaç Helvası}

İç malzemesi un, şeker ve yağdır. Yaklaşık 250 gr un içerisine yarım çay bardağı su/süt karıştırılarak, elde edilen karışım iyice ovulur. Elde edilen karışım bir elekte elenir, elek üzerinde kalan karışım 250 gr erimiş yağ içerisine öncelikli atılarak hafif pembeleşinceye kadar kavrulur. Geriye kalan karışım da eklenerek kısık ateşte tüm malzemeler iyice kavrulur. Yaklaşık yarım litre su ile karıştırılmış şeker, bu kızarmış karışıma katılır ve ateş üzerinde kıvam tutuncaya kadar karıştırılır. Elde edilen umaç helvası isteğe göre uygun bir kap üzerinde servis edilir. Görsel 5. 


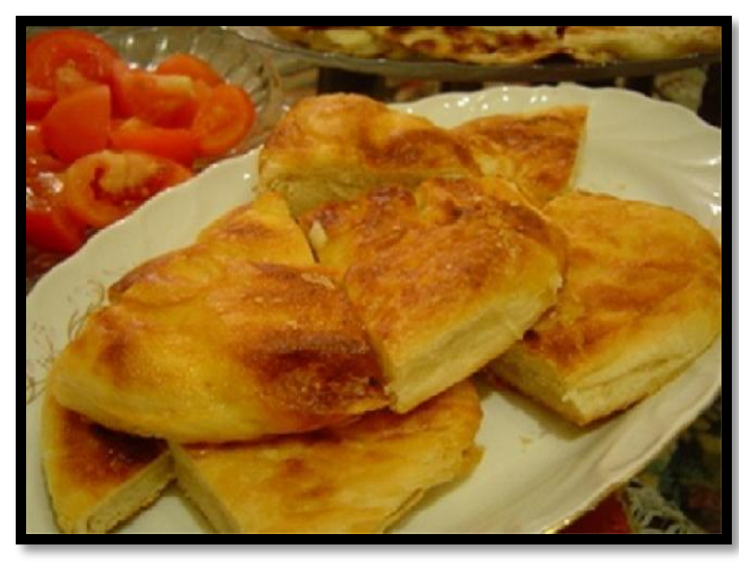

Görsel 4: Kete

Kaynak: Kars İl Kültür ve Turizm Müdürlüğü

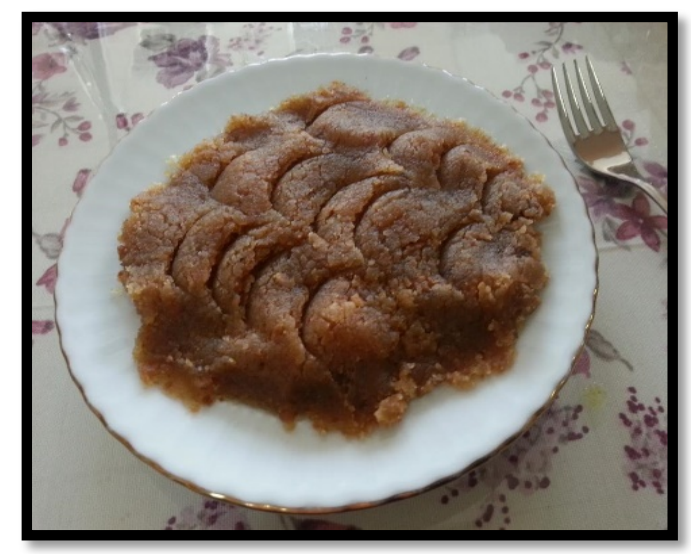

Görsel 5: Umaç Helvası

Kaynak: Kars İl Kültür ve Turizm Müdürlüğü

\section{Kars Yöresel Çorbaları}

\section{Hörre Aşı}

Un yağda iyice pembeleşinceye kadar kavrulur. Kavrulmuş karışım içerisine yeterince su ilave edilerek çorba kıvamına getirilene kadar karıştırılır, karışım kaynamaya başlayınca, yaklaşık 2-3 dakika kaynatılarak çorba hazır hale getirilir.

\section{Evelik Aşı}

Evelik yaz aylarında yetişen doğal bir bitkidir. Bu bitkiler Ağustos ayında toplanır ve temizlenerek kış aylarında kullanmak üzere kurutulur. Kurutulmuş bu bitkiden kışın çorbalar yapılarak tüketilir. Evelik çorbası içerisine yağ, soğan, salça, evelik, isteğe göre yeşil mercimek, patates karıştırılarak pişirilir.

\section{Erişte Aşı}

Erişte aşının iç malzemeleri un, yağ, soğan, yeşil mercimektir. Bir miktar un içerisine su ve tuz katılarak küçük bir beze hamur elde edilir. Elde edilen hamur çok ince olmayacak şekilde açılır ve üzeri iyice unlanır. Unlanan yufka önce dört kat halinde uzunca katlanır ve yine iyice unlanır. Bir bıçak yardımıyla yufka ince dilimler halinde kesilir. Çorba için biraz yağ ve soğan bir kap içerisinde kavrulur ve üzerine su ilave edilir ve kaynamaya bırakılır kaynayan karışım içerisine ayrı bir kapta haşlanıp süzülen yeşil mercimek ilave edilir. Elde edilen bu karışım biraz kaynatıldıktan sonra kesilerek hazırlanmış hamurlar da eklenerek pişirilmeye devam edilir ve pişen çorba artık servis edilmeye hazırdır.

\section{Ayran Aş1}

Bu çorba Kars yöresinde şeker pancarı yapraklarıyla yapılır. Şeker pancarı yaprakları temizlenip yıkandıktan sonra bir kap içerisine çok büyük olmayacak şekilde doğranır. Doğranmış şeker pancarı yaprağı içerisine isteğe göre bir miktar yarma (ögüüülmüş kırık bulgur), pirinç ve su katılarak ayrı bir kapta haşlanır. Ayrıca bir kapta biraz yoğurt içerisine bir yumurta ve biraz un 
katılarak iyice karıştırılır. Pişmiş ve soğutulmuş şeker pancarı yaprağı karışımı içerisine yoğurt karışımı eklenir ve yeteri kadar da su eklenerek karışım kaynayıncaya kadar iyice karıştırılır. Pişmiş çorba üzerine bir baş soğan yağda kavurularak eklenir ve iyice karıştırılarak çorba servis edilir.

\section{Kars'1n Gastronomik Ürünü Kaz}

Gastronomik kimlik, "bir topluma ait beslenme şekilleri, yiyeceklerin üretimi, hazırlanması ve tüketimi ile ilgili, toplumun kültürünü ve benliğini tasvir edecek kadar özgü, onu diğerlerinden ayıracak kadar özdeşleşmiş özellikleri anlatmak adına kullanılan bir olgudur" (Diker ve Deniz, 2017:191). Gastronomik kimlik olgusu, bir topluma ait, yöresel yemek ve içeceklerin üzerinde çevresel şartların (coğrafik yapı ve iklim) ve kültürün etkisinin görüldüğü bir bütünü ifade etmektedir (Harrington, 2005:131). Kars kazı Kars yöresinin en önemli gastronomik ürünü haline gelmiştir.

Kars yöresel mutfağında kurutulmuş kaz etinden yapılmış yemeklerin çok özel bir yeri vardır. Kış aylarının en özel günleri ve en özel misafirleri için kaz eti pişirilir. Kaz eti ile ağırlanan misafirlerde kendilerini oldukça özel hissederler. Kaz eti yemekleri Kars yöresinin en özel yemeğidir. Kaz, yörenin sadece geleneksel mutfak kültürü ve yemeklerinde değil, yöre halkının kültüründe, sosyal yaşantısında çok önemli roller üstlenmiştir. Halk edebiyatında, hikâyelerinde, şiirlerinde, fıkra, mani, atasözü, inanış, türkü ve halk oyunlarında en çok işlenen hayvan kazdır. Kars ilinde yaşayan Karapapak Terekeme'lerinin has yemeği olan kaz ile ilgili en çok kullanılan deyim "Karapapă̆ın babasını öldür sana düşmanlık beslemez, kazını öldür sana kan davası güder" sözüyle kazın önemi vurgulanmıştır. Kaz yörede yaşayan insanların el sanatlarında yer edinmiş bir hayvandır. El işlemelerinin çoğunda kaz figürlü işlemeler çokça kullanılmıştır. Kaz yöre halkı ile özleşerek hem kültürel, sosyal hem de ekonomik hayatının en önemli bir parçası haline gelmiştir. Kars kazının pek çok kullanım alanı vardır. Yerel yaşamda kazın tüyünden yastık yapılır. Kaz tüyü olmayan yastık halk tarafından kabul görmez. Kazın içinden elde edilen yağ, yörede sıkça kullanılır. Kaz yağından çeşitli kızartmalar ve yemekler yapılır. Kaz içinden çıkan tüm iç malzemeler (yürek, taşlık, bağırsaklar) ve sakat atları (baş ve ayaklar) yörede sevilerek tüketilir.

Günümüzde bazı aileler geçimlerini kaz yetiştiriciliğinden sağlamaktadırlar. İlaveten, il dışında büyük şehirlerde çok özel otel ve restoranlar menülerine haftanın belli günleri için Kars kaz eti eklenmiş, hatta sadece kaz etinin ikram edildiği özel kaz geceleleri düzenlenmektedir.

Kars yöresinde kaz yemeklerinin ne zamandan beri pişirildiğine dair yazılı bir bilgiye rastlanılmamıştır. Ancak Eski çağa ait arkeolojik belgeler bizlere bazı kanıtlar sunmuştur. M.Ö. II. bin yılı başlarına ait olduğu kabul edilen höyük ve kurgan türü mezarlarda bulunan çanak ve çömlekler üzerine resmedilen hayvanlar arasında kaz, su kuşları ve ördeklere çokça rastlanmıştır. $\mathrm{Bu}$ sonuç bize bu hayvanların insanlarla iç içe olduğunu ve bir arada yaşadıklarını göstermektedir. Kuş, ördek ve kaz resimlerinin kökeni günümüzden 4000 yıl öncesine kadar gitmektedir. Kars yöresinde Urartu krallı̆̆ dönemine ait kemer ve barkaçlar üzerinde kaz, ördek, tavuk ve horoz figürlerinin olduğu ancak; çizgi tekniği ile işlenmiş kaz resimlerine daha çok rastlanmıştır. Tüm bu kanıtlar ışı̆̆ında Urartu döneminde kazların evcilleştiğini ve insanlarla bir arada yaşadıklarını söyleyebiliriz. Ancak yazılı kaynakların olmaması nedeniyle Doğu Anadolu Mutfak kültürü ile ilgili fazla bilgiye ulaşılamamaktadır. Kafkasya ile Doğu Anadolu arasında bir köprü görevi gören Kars yöresinin yemek kültürü yaşanan göçler ve savaşlar nedeniyle bir süreklilik göstermemektedir. Türklerin 1071 Malazgirt zaferinden sonra Anadolu'ya göç etmeleri ve yerleşik yaşamın sürekli hale gelmesiyle beraber, yemek kültüründe büyük ve uzun süre devam edecek bir birikim oluşmaya başlamıştır (Belli ve Belli, 2012: 129). 
Kars yöresi, coğrafik yapısı, iklimi ve yetiştirilen büyükbaş ve küçükbaş hayvanları, kümes hayvanları ve nebatları ile insanların beslenme alışkanlıkları ve damak zevklerinin belirlenmesinde katkıda bulunmuştur. Kars Kazı bölgenin iklimi, coğrafik yapısı ve bitki örtüsü ile büyük bir uyum yakalayarak, bölgenin en çok beslenen kümes hayvanı olmuştur.

Kars bölgesi mutfak kültüründe yüzlerce yıldan beridir yapılan kaz yemeklerinin en yaygın pişirme şekli tandırda kaz çekmesi ve fırında kazdır. Kaz denilince ilk akla gelen il Kars'ır. Nedeni Kaz kazının başka yerlerde yetişen kazlardan daha lezzetli olmasıdır. Kars kazının yörenin iklimi ile uyumu etin lezzetine de yansımıştır. Kazlar Kars'ta kar yağmadan kesilmez, nedeni ise kar yemeyen kazın lezzetli olmayacağ 1 inanışıdır. Bu nedenle kazın kesim tarihi karın yağmasına paralel belirlenir (Belli ve Belli, 2012: 130).

İlk evcil kümes hayvanı olan kaz, diğer kümes hayvanlarına göre soğuk hava koşullarına daha dayanıklı hayvanlardır. Kimyasal kalıntı riskinin düşük olduğu ve kaz etinin içeriğinde yer alan zengin omega 3 ve demir nedeniyle kaz eti güvenilir bir besindir (Gündüz vd., 2019). Kaz eti protein değeri yüksek ve arginin gibi insan sağlığına faydalı aminoasitler ve yüksek oranda doymamış yağ asitleri içermesi sebebiyle insan beslenmesi için önemli bir besin kaynağıdır (Liu vd., 2011). Kazlar selüloz içeriği yüksek otları ve yemleri kolaylıkla sindirebilen, sert hava şartlarına ve hastalıklara dayanıklı bir hayvanlardır (Labatut, 2002). Kaz eti yüksek besleyici değeri ve düşük yağ ve kolesterol içeriği sebebiyle sağlıklı bir ettir (Diker ve Deniz, 2017: 190).

Kaz etinin geleneksel pişirilme şekli tandırda kaz çekmesidir. Kazlar bütün olarak geniş bir tencere içerisinde haşlanır. Haşlanmış haldeki kazın boynuna tel bağlanarak alevlenmenin tamamen durduğu tandıra bir şiş yardımıyla asılır. Kazın altına ise bir tencere konulur, tencerenin içerisine haşlanmış kazın suyu konulur ve içerisine yöresel bulgur dökülür. Kaz piştikçe yağları erir ve altındaki bulgur pilavının içine dökülür. Bu işlem kaz iyece kızarana kadar devam eder. Görsel 6, Görsel 7.

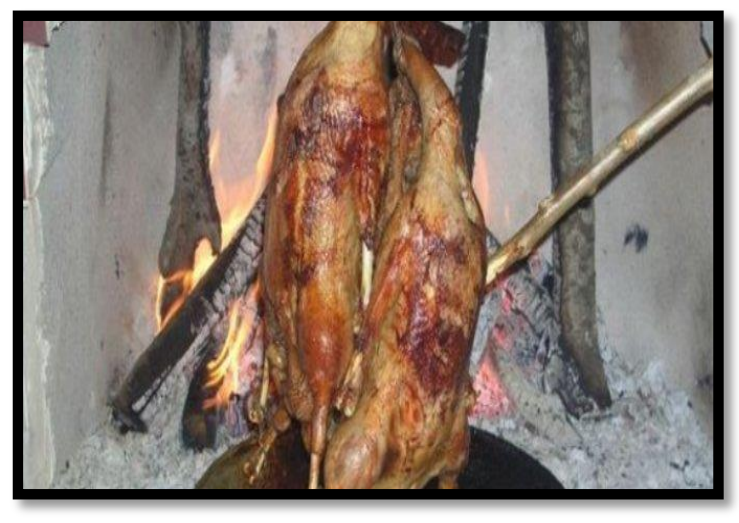

Görsel 6: Tandırda Kaz Çekmesi

Kaynak: Kars İl Kültür ve Turizm Müdürlüğü

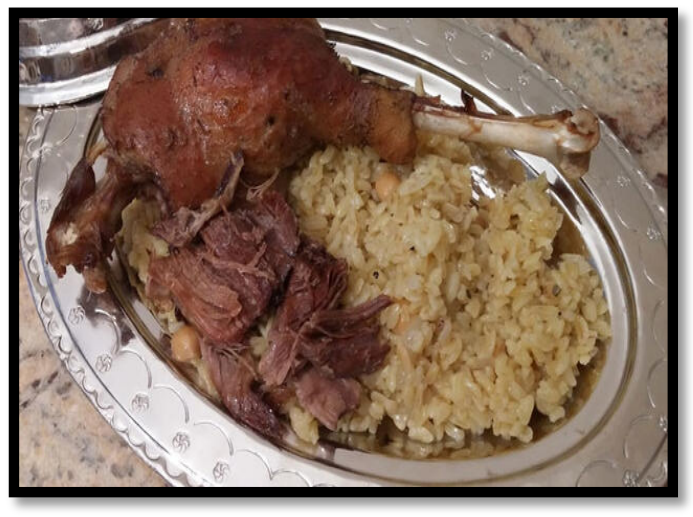

Görsel 7: Kars Kazının Servis edilme şekli

Kaynak: www.google.com/search?q=Kaz+yemekleri

\section{YÖNTEM}

Araştırma için, TripAdvisor sitesinden Kars restoranları bölümünde yer alan en iyi 10 yiyecek içecek işletmesi belirlenmiştir. Bu çalışmada nitel araştırma yöntemi ve yarı yapılandırılmış görüşme formu kullanılmıştır. Bu araştırma formunda, yiyecek içecek işletmelerinde yerel gıda ürünlerinin ve özellikle Kars kazının mevcudiyet seviyesinin ne olduğuna yönelik sorular yer almıştır. Soru formunun ilk 5 sorusu için (Sormaz, 2017; Özdemir vd., 2015; Culha ve Dağkıran, 2016)' nın çalışmasından yararlanılmış ve Kars İl'ine uyarlanmıştır. İlaveten işletme menülerinde 
yöresel çorba, yemek, tatlı ve ürünler kullanılıp kullanılmadığını öğrenmek için kapalı uçlu sorular işletme yönetimine yöneltilmiştir. Çalışmaya katılmayı kabul eden 10 yiyecek ve içecek işletmesinin temsilcisi şef / işveren / yöneticiler çalışmanın örneklemini oluşturmuştur. Kalıcı yüz yüze görüşmeler Ocak 2020 ayı içerisinde işyerlerinde katılımcılarla 15-45 dk. yapılmış ve katılımciların sesleri kaydedilmiştir.

\section{BULGULAR}

\section{Demografik ve Tanımlayıcı Bulgular}

Demografik özellikler cinsiyet, yaş, eğitim ve yöneticinin pozisyonu Tablo 1'de mevcuttur. Bu tabloya göre, katılımcıların çoğunluğu $(n=8)$ erkek; katılımcıların yarıdan fazlası $(n=7) 31$ ile 41 yaşları arasında; yine katılımcıların yarıdan fazlası $(n=7)$ üniversite mezunudur. Çalışanların pozisyonları ( $\mathrm{n}=6)$ yarıdan fazlası restoran müdürüdür. İşletmelerin faaliyet yıllı, $(\mathrm{n}=4)$ 4-10 yıl arasında, (n=3) 1-3 yıl arasında, (n=2) 11-20 arasında, $(n=1)$ 21-30 yıl ve 31 ve üzeridir.

Tablo 1: Demografik ve Tanımlayıcı Bilgiler

\begin{tabular}{|l|c|}
\hline Demografik ve Tanımlayıcı Bulgular & Işletme Sayısı (n) \\
\hline Erkek & 8 \\
Kadın & 2 \\
Yaş & \\
$20-30$ arası & 1 \\
$31-40$ arası & 7 \\
41 -50 arası & 1 \\
51 ve üstü & 1 \\
Eğitim & \\
İlköğretim & 1 \\
Lise & 2 \\
Yüksekokul & 3 \\
Lisans & 4 \\
Pozisyon & \\
Şef & 1 \\
Restoran müdürü & 6 \\
İşletme Sahibi & 3 \\
İssletme Faaliyet Yılı & \\
1-3 yıl arası & 3 \\
4-10 yıl arası & 4 \\
11-20 yıl arası & 2 \\
21-30 yıl arası & 1 \\
31 yıl ve üzeri & 1 \\
\hline
\end{tabular}

\section{Yerel Gıda Ürünlerinin İşletme Menülerine Dahil Edilme Durumu}

Bölgesel ekonomik ve kültürel gelişmenin sağlanması ve sürdürülmesi için, bir bölgede üretilen yerel gıda ürünlerinin kullanımı önemlidir. Bu yerel gıda ürünlerinin mutfaktaki kullanım düzeylerinin ve yerel gıdaların işletmelerin menülerindeki sunum düzeylerinin değerlendirilmesi bu çalışmanın amacı olmuştur. 
Kars merkezde yer alan 10 yiyecek İçecek işletmelerine açık uçlu olarak sorulan menünüzde hangi yöresel yemekler var? Sorusuna verilen cevaplar aşağıdaki grafikte gösterilmiştir. Grafik 1'e göre, İşletmelerin \% 100'ü Kars kazı ve Umaç helvasını; \%60'ı Pitiyi, \% 60'ı Hangeli, \%60' 1 ise Haşılı işletme menülerine dâhil etmişlerdir.

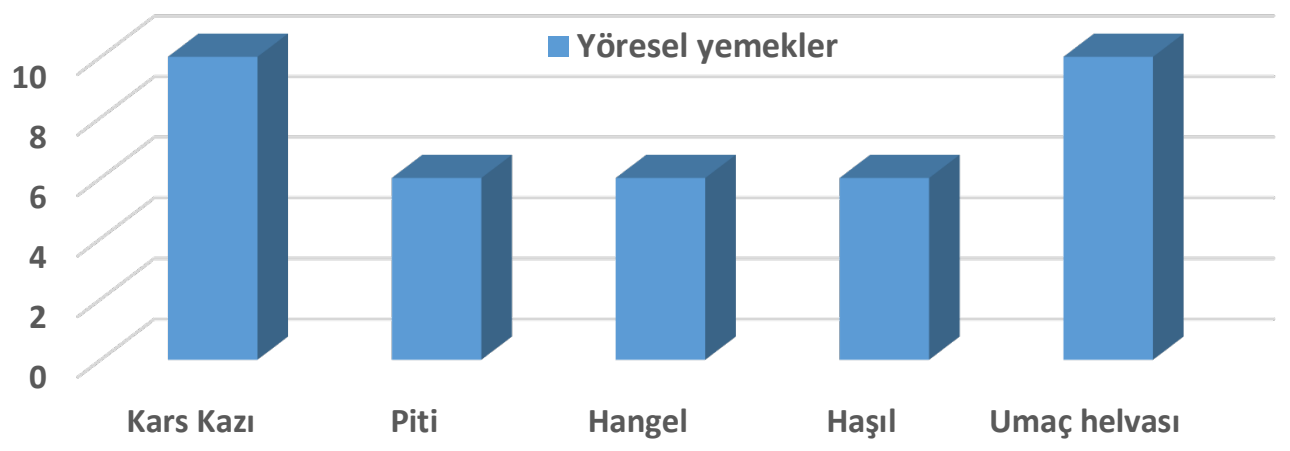

Grafik 1: İşletme Menülerinde Yer Alan Yöresel Yemekler

Kars merkezde yer alan 10 Yiyecek İçecek işletmelerine açık uçlu olarak sorulan menünüzde hangi yöresel çorba var? Sorusuna verilen cevaplar aşağıdaki grafikte gösterilmiştir. Grafik 2'e göre, İşletmelerin \%100'ü Evelik aşı ile Ayran aşını; \%60'ı ise Hörre aşı ve Erişte aşını işletme menülerine dahil etmişlerdir.

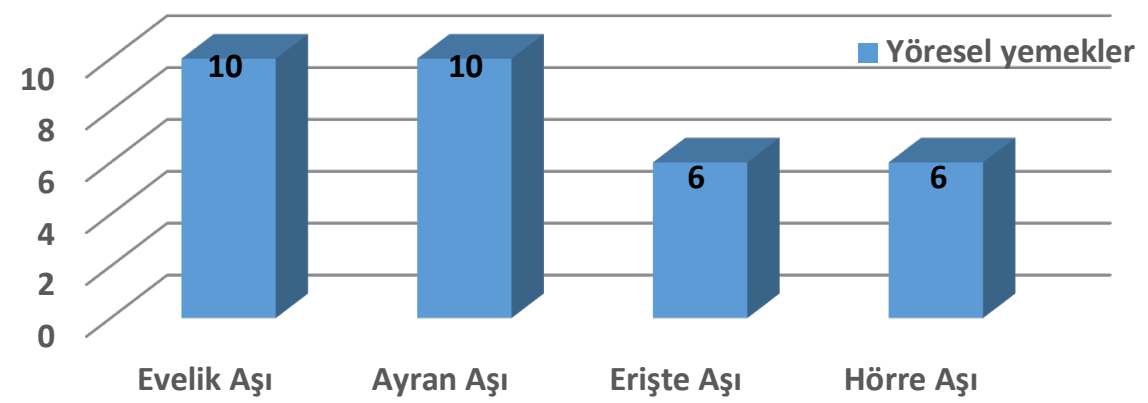

Grafik 2: İşletme Menülerinde Yer Alan Yöresel Çorbalar

Kars merkezde yer alan 10 Yiyecek İçecek işletmelerine açık uçlu olarak sorulan işletmenize gelen turistler hangi yöresel yiyecekleri daha çok tercih ediyor? Sorusuna verilen cevaplar aşağıdaki grafikte gösterilmiştir. Grafik 3'e göre, İşletmelerin \%100'ünde kaz, \%60'ında ise Umaç helvası, Evelik aşı ve Piti, \%40'ında ise Erişte aşı, Haşıl ve Hangel cevabı verilmiştir. 


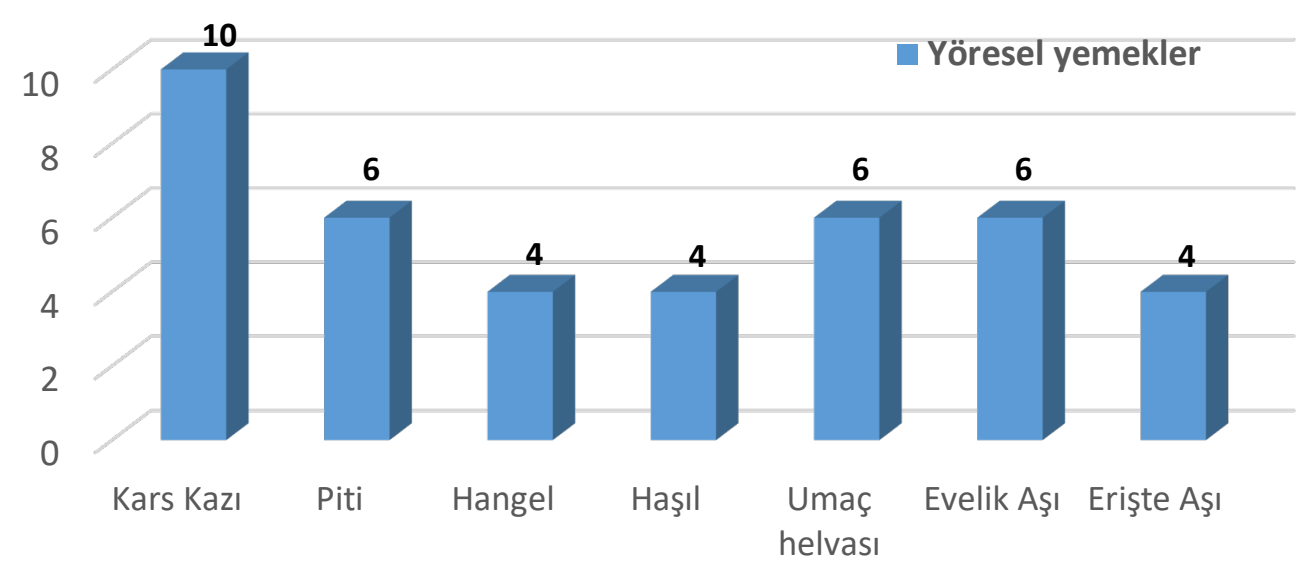

Grafik 3: İşletmeye Gelen Turistlerin En çok Tercih Ettiği Yöresel Ürünler

Kars merkezde yer alan 10 yiyecek İçecek işletmelerine açık uçlu olarak sorulan Kars kazı Kars'ın gastronomik ürünü mü? Sorusuna verilen cevaplar aşağıdaki grafikte gösterilmiştir. Grafik 4'e göre, işletmelerin \%100'ünde evet yanıtı verilmiştir.

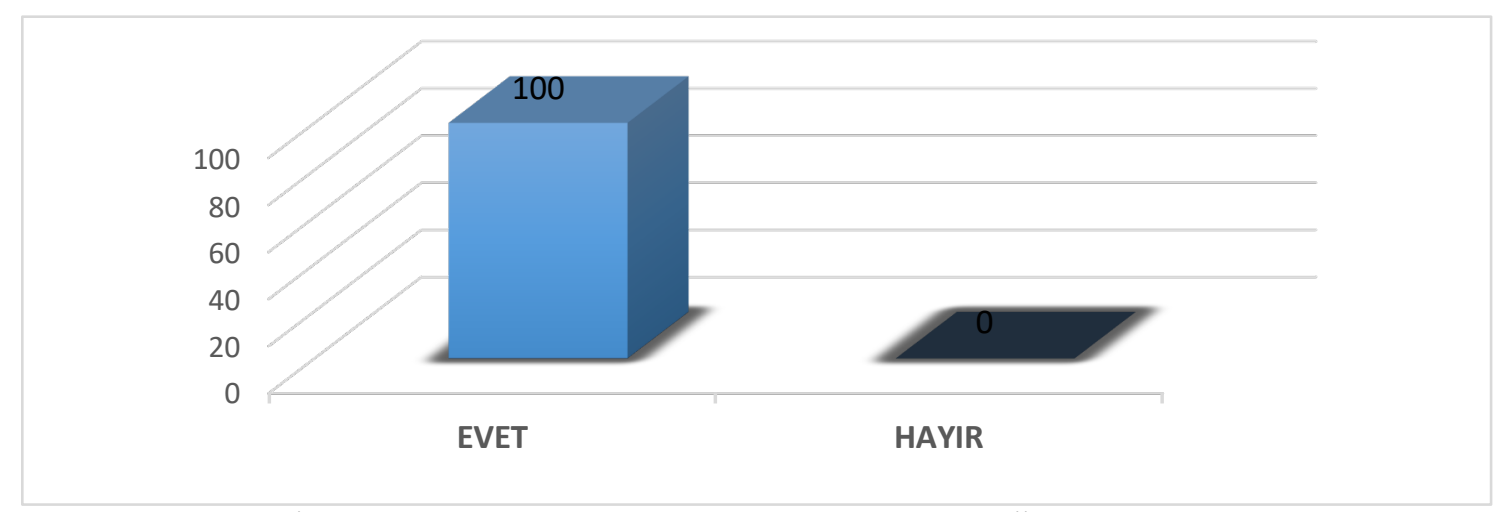

Grafik 4: İşletme Çalışanlarının Kars Kazı Gastronomik Ürün Değerlendirmesi

İşletmelere yöneltilen Kars kazı niçin Kars'ta yenmelidir? Sorusuna verilen cevapların ortak özelliği, kazın soğuk iklim sevdiği ve Kars ikliminin kaz yetiştiriciliği için çok uygun olduğu, kazın doğal ürünlerle beslendiği ve meralarda otlatıldığıdır. Kazın kesim zamanına tüm görüşmeciler tarafından vurgu yapılmış ve kazın havalar iyice soğumadan kesilmediği ve özellikle karın yağmasının beklendiği ifade edilmiştir. Kaz etinin içerisindeki toksinleri temizlemek, kaz etinin yağ oranını dengelemek ve etin kokusunu azaltmak için kar yedirilmesi gerektiği ise tüm katılımcılar tarafından ifade edilmiştir. Kaz kesim ve saklama koşullarının da kaz etinin lezzetini artırdığı kanısı tüm katılımcılar tarafından ifade edilmiştir. Kaz kesildikten sonra temizlenir ve iyice yıkanarak tuzlanır. Tuzlanan kazlar uygun bir yere asılır ve sürekli kontrol edilerek yaklaşık 1 hafta kurutulur. Kurumuş kaz etinin daha lezzetli hale geldiği tüm katılımclar tarafından belirtilmiştir.

\section{Yerel Gıda Ürünleri İçin Sürdürülebilir Gıda Algısı}

Yerel gıda ürünlerinin yakın alanlardan temini çevresel açıdan sürdürülebilirlik olgusuna katkı sağlar. Yerel gıda ürünlerinin üretildiği yerlerde tüketilmeleri gıdanın temel özellikleri, maliyet, 
zaman ve mesafe açısından avantajlar sağlamaktadır. Ayrıca mutfak kültürünün sürdürülebilirliği açısından bölge ekonomisine katkı sağlar (Öztürk ve Akoğlu, 2020).

Katılımcılara öncelikle gıda sürdürülebilirliği hakkında bilgilendirme yapılmış ve Yiyecek içecek işletmelerinin yerel gıda tercihinin gıda sürdürülebilirliği açısından önemli olup olmadığı sorusu sorulmuştur. Bir katılımcının ifadesi şu şekildedir:

“Bu ürünlerin tüketimi artıkça sürdürülebilirliği de artar. Yerel ürünlerin üretiminin artırllması için üreticilerin desteklenmesi ve teşvik edilmesi gereklidir. Ben yerel ürünlerin tanıtılması ve gelecek nesillere aktarılması gerektiğini düşünenlerdenim ve haklı olduğumu da gördüm. Kars'ta ilk yerel ürün işletmesi açan benim ve Kars yerel mutfak ürünlerinin tanıtılmasına ve sürdürülebilir hale gelmesine katkı săgladım. Son yillarda, özellikle turistler yiyecek içecek işletme menülerinde yerel ürünler görmek istiyorlar. Bu ürünlere yönelik talep artarsa, sürdürülebilirlik să̆lanmış olur"

İşletmelerin sadece birinde gıda tercihlerinde gıda sürdürülebilirliği algısının olduğu gözlenmiştir. Diğer işletmelerin ifadeleri aşağıdaki şekilde özetlenmiştir:

İşletme menülerine yerel grdalarm dahil edilmesinin nedeninin talep olduğunu ifade etmişlerdir. Son yıllarda yerel mutfak ürünleri özellikle turistler tarafindan daha çok tercih ediliyor. Özellikle kaz eti en çok tercih edilen üründür. Kaz etinin kış aylarında temin edilebildiği ve kışın tüketilen bir gıda olduğu ifade edilmiştir. Yerel mutfağın yerel kültürümüzün bir parçası olduğunu ve mutfak kültürünü korumak için de bu ürünleri işletme menülerine dahil ettiklerini ifade etmişlerdir. Yerel gıda temini ile ilgili herhangi bir sorun yaşamadıkların hatta tüketicilerin ürümlerini daha kıymetli hale getirdiklerini belirtmişlerdir.

Son olarak, gıda sürdürülebilirliği ile ilgili verdiğimiz bilgiler memnuniyetle karşılanmış ve çoğu işletme tarafından menülerine daha çok yerel yemek dahil etme isteklerinin olduğu ifade edilmiştir. Sürdürülebilirliğin tüm işletmeler için bir motivasyon kaynağı olarak görülmediği, İşletmelerden sadece birinin gıda sürdürülebilirliği algısına sahip olduğu, mutfak kültürünü sürdürülebilir hale getirmek ve geliştirmek ise tümünün hedefleri arasında olduğu belirlenmiştir. Yerel gıda ürünlerinin yiyecek ve içecek işletmelerinde yer alma nedeninin sürdürülebilir gıda bilinci ile yapılmadığı sonucuna varılmışır.

\section{SONUÇ}

$\mathrm{Bu}$ araştırmanın konusu Kars'ın yerel yemekleri ve yerel ürünlerin Kars'taki yiyecek içecek işletmelerinde kullanımının sürdürülebilir gıda kapsamında değerlendirilmesidir. Kars Türkiye'nin en doğusunda ve Ermenistan ile sınır olan bir ildir. Kendine has iklim özellikleri sayesinde yöreye özgü ürünleri vardır. Yöresel mutfağı zengin olan Kars'ın yerel yemekleri işletme menülerinde yer almıştır. İşletme menülerinde yer alan yöresel yemekler Hangel, Haşıl, Kars Kazı, Piti, Kete, Umaç Helvasıdır. Yöresel çorbalar ise Hörre aşı, Evelik aşı, Erişte aşı ve Ayran aşıdır.

İşletmelere yöneltilen Kars kazı niçin Kars'ta yenmelidir? Sorusuna verilen cevapların ortak özelliği, kazın soğuk iklim sevdiği ve Kars ikliminin kaz yetiştiriciliği için çok uygun olduğu, kazın doğal ürünlerle beslendiği ve meralarda otlatıldığıdır. Kazın kesim zamanına tüm görüşmeciler tarafından vurgu yapılmış ve kazın havalar iyice soğumadan kesilmediği ve özellikle karın yağmasının beklendiği ifade edilmiştir. Kaz etinin içerisindeki toksinleri temizlemek, kaz etinin yağ oranını dengelemek ve etin kokusunu azaltmak için kar yedirilmesi gerektiği ise tüm katılımcılar tarafından ifade edilmiştir. Kaz kesim ve saklama koşullarının da kaz etinin lezzetini artırdığı kanısı tüm katılımcılar tarafından ifade edilmiştir. Kaz kesildikten sonra temizlenir ve iyice yıkanarak tuzlanır. Tuzlanan kazlar uygun bir yere asılır ve sürekli 
kontrol edilerek yaklaşık 1 hafta kurutulur. Kurumuş kaz etinin daha lezzetli hale geldiği tüm katılımcılar tarafından belirtilmiştir.

Çalışmada katılımcılara sürdürülebilirlik algısı sorulduğunda, sürdürülebilir gıda bilgisinin yetersiz olduğu görülmektedir. Yerel gıda tercihinin sürdürülebilirlik algısı çerçevesinde sadece bir işletme tarafından uygulandığı görülmektedir. Sonuç olarak, yerel gıda ürünleri bu örnek için yiyecek ve içecek işletmelerinde yer alırken, bunun sürdürülebilir gıda bilinci ile yapılmadığı sonucuna varılmıştır. Yerel gıda kullanımında sürdürülebilirlik bilinci oluşturmak hem yerel gıda kullanımının artmasına hem de gıdanın sürdürülebilirliğine katkıda bulunacaktır.

Kızılırmak vd.,2014; Kaşlı vd., 2015; Öztürk ve Akoğlu, 2020 çalışmalarında gastronomik mirasların korunması gerektiğini ve bölgelerin kültürünü yansıtan en önemli faktörler arasında yer alan mutfak kültürü sürdürülebilirliğinin gelecek nesillere kültürel aktarımın önemini vurgulamışlardır. Bu nedenle yerel mutfak kültürü menülerde daha fazla korunmalı, kaydedilmeli ve daha fazla ele alınmalıdır. Bu nedenle Kars mutfağı ile ilgili gelecekte daha kapsamlı ve derin bir araştırmalar yapılabilir veya mevcut durum müşteriler ve turistler açısından değerlendirilebilir.

Yiyecek ve içecek işletme çalışanlarının gıda sürdürülebilirliği ile ilgili farkındalık düzeyleri artırılmalıdır. Özellikle bakanlıklar, belediyeler ve üniversiteler dernekleri / federasyonları bu bilinci artırmak için işbirliği içinde çalışmalar yapabilirler. Yerel üreticileri destekleyen düzenlemeler ve teşvikler verilebilir. Yerel mutfağı korumak için kayıt çalışmaları desteklenmeli, yerel gıdaların kültürün gelecek nesillere aktarılmasındaki önem vurgulanmalı ve hak ettiği değer takdir edilmelidir.

\section{KAYNAKÇA}

Atay Haspolat, N. (2015). Gıda Güvenliğinde Sürdürülebilir Gıda Sistemler. AB Uzmanlık Tezi. Gıda Tarım ve Hayvancılık Bakanlığı. Ankara.

Bayat, G. (2018). Gastronomi Turizmi Kapsamınsa Yiyecek İçecek Menülerinde Yöresel Mutfağın Kullanımı: Iğdır İli Örneği. Turamsam Dergisi. 40, 757-762.

Bayat, G., ve İşlek, E. (2019). Türk Mutfağı Kapsamında Yöresel Mutfağın Yöre Halkı Tarafından Tanınma Durumunun Tespit Edilmesi: Iğdır İli Örneği. Avrasya Eğitim ve Literatür Dergisi. UTKM Özel Sayı, 589-594.

Belli, O., ve Belli, G. S. (2011). Kars Bölgesi'nde Kaz Etinden Yapılan Yemekler. III. Uluslararası Doğu Anadolu Bölgesi Geleneksel Mutfak Kültürü ve Erzurum Yemekleri Sempozyumu, s: 128138.

Demirbaş, N., Oktay, D. ve Tosun, D. (2006). AB Sürecindeki Türkiye'de Gida Güvenliği Açısından Geleneksel Gıdaların Üretim ve Pazarlaması. Harran Üniversitesi, Ziraat Fakültesi Dergisi, 10 (3-4), 47-55.

Diker, D. (2017). Kars Kültürel ve Gastronomik Kimliğinde Kaz. Doğu Coğrafya Dergisi, 38, 189204.

Doğan, O; and Yağmur, Y. (2017). Foreign Tourists' Sustainable Destination Perceptions: A research on Kemer Destination. Int. J. Manag. Econ. Bus., 13(2), 487-506.

Gündüz, S., Dölekoğlu, C., ve Say, D. (2019). Kaz Eti Tüketim Tercihleri ve İkama Ürünlerde Duyusal Analiz. Avrupa Bilim ve Teknoloji Dergisi. 16, 32-40. 
Harrington, R.J., and Ottenbacher, M.C., (2010). Culinary Tourism, A Case Study of the Gastronomic Capital. Journal of Culinary Science \& Technology, 8, 14-32.

https://www.google.com/search?q=Kaz+yemekleri\&sxsrf=ALeKk01jVcdl6DjrDf44RcXgoeGET3s cMA:1583153335769\&tbm=isch\&source=iu\&ictx=1\&fir=3uKKaP2B9IRcjM\%253A\%252CE1TKr3p g5rdELM\%252C_\&vet=1\&usg=AI4_-

kRPctXQ4J5RkgCmrvsLGkOg_8Ri8g\&sa=X\&ved=2ahUKEwiLg9Dh6fvnAhWjsXEKHdbeACce neQ9QEwDXoECAkQFA\#imgrc=3uKKaP2B9IRcjM: Erişim Tarihi: 02.03.2020, Saati: 15:49.

https://kars.ktb.gov.tr/ Erişim Tarihi: 02.03.2020, Saati: 16:05

Kaşlı, M., Cankul, D., Koz, E.N., ve Ekici, A. (2015). Gastronomi Miras ve Sürdürülebilirlik: Eskişehir Örneği. Eko-gastronomi Dergisi. 1(2),27-46.

Kang, S., and Rajagopal, I. (2014). Perceptions of benefits and Challenges of purchasing local foods among hotel industry decision makers, J. Foogserv.Bus. Res.,17, 301-322.

Kelemci Schneider, G., and Ceritoğlu, B. (2010). The role of the local products in a global World an investigation in İstanbul. Pazarlama ve Pazarlama Araştırmaları Dergisi 6, 29-52.

Kızılırmak, İ., Albayrak, A., and Küçükali, S. (2014). Implementation of regional cuisine in rural tourism businesses. Soc. Econ. Scl., 4(1), 75-83.

Kim, Y. G., Eves, A., and Scarles, C. (2013). Empirical verification of a conceptual model of local food consumption at a tourist destination. International Journal of Hospitality Management, 33, 484489.

Labatut, M. C., 2002. Goose production in Chile and South America. Ed. Buckland, R., Guy G., Goose Production. p. 93-111. FAO Animal Production and Health Paper-154, Roma, İtalya.

Lehtinen, U. (2012). Sustainability and Local Food Procurement: A case Study of Finnish Public Catering. Br, Food. J., 114(8), 1053-1071.

Liu B.Y., Wang, Z.Y., Yang, H.M., Wang, J.M. Xu, D., Zhang, R., and Wang, Q., (2011). Influence of rearing system on growth performance, carcass traits, and meat quality of Yangzhou. Poultry Science, 90(3): 653-659.

Long, L. M. (2003). Culinary tourism. Lexington: The University Press of Kentucky

Özdemir, B., Yılmaz, G., Çalışkan, O., ve Aydın, A. (2015). Şeflerin Yerel Yiyeceğe İlişkin Algılamaları ile Yerel Yiyecek Satın Alma Niyetleri Arasındaki İlişki. 16.Ulusal Turizm Kongresi, Çanakkale, Detay Yayıncılık, Ankara, s:418-437.

Öztürk, S. N., Akoğlu, A. (2020). Assessment of Local Food Use in the Context of Sustainable Food: A research in Food and Beverage Enterprises in İzmir, Turkey. International Journal of Gastronomy and Food Science, 20, 100194.

Sormaz, Ü. (2017). Yöresel Mutfak Tanıtımında Yerel Restoranların Etkisi: Konya Örneği. Journal of Tourism and Gastronomy Studies, 5(2), 160-173.

Şengül, S., ve Türkay, O. (2015), Doğu Karadeniz mutfak kültürünün sürdürülebilirliği sorunlar ve çözüm önerileri. Doğu Karadeniz Bölgesi Sürdürülebilir Turizm Kongresi Bildiri Kitabı, 599606.

Tan, E. (2009). Türkiye Geleneksel Gıda Ürünleri Projesi, II. Geleneksel Gıdalar Sempozyumu, 27-29 Mayıs 2009, Van, İndirilme Tarihi: 27 Haziran 2010,

www.gelenekselgidalar.com/dosyalar2/view.php?file=Enver+Tan.pdf 
Wilk, R. (2006). Home cooking in the global village: Caribbean food from buccaneers to ecotourists. London: Berg. 